\title{
Hypofractionated Radiation Therapy for Large Brain Metastases
}

\author{
Giuseppina Laura Masucci* \\ Department of Radiation Oncology, Centre Hospitalier de l'Université de Montréal, Montreal, QC, Canada
}

Single fraction radiosurgery (SRS) treatment is an effective and recognized alternative to whole brain radiation for brain metastasis. However, SRS is not always possible, especially in tumors of a larger diameter where the administration of high dose in a single fraction is limited by the possibility of acute and late side effects and the dose to the surrounding organs at risk. Hypofractionated radiation therapy allows the delivery of high doses of radiation per fraction while minimizing adverse events, all the while maintaining good local control of lesions. The optimal dose fractionation has however not been established. This overwiew presents available evidence and rationale supporting usage of hypofractionated radiation therapy in the treatment of large brain metastases.

Keywords: large brain metastasis, hypofractionation, stereotactic radiotherapy, radiosurgery, brain metastasis

\section{OPEN ACCESS}

Edited by:

Arjun Sahgal,

University of Toronto, Canada

Reviewed by:

Riccardo Soffietti,

Università degli Studi di Torino, Italy David M. Peereboom,

Cleveland Clinic Lerner College of

Medicine, United States

*Correspondence:

Giuseppina Laura Masucci

g.laura.masucci.chum

@ssss.gouv.qc.ca

Specialty section:

This article was submitted to

Neuro-Oncology and Neurosurgical

Oncology,

a section of the journal

Frontiers in Oncology

Received: 02 June 2018

Accepted: 23 August 2018

Published: 02 October 2018

Citation:

Masucci GL (2018) Hypofractionated Radiation Therapy for Large Brain Metastases. Front. Oncol. 8:379. doi: 10.3389/fonc.2018.00379
Brain metastases (BM) are a common occurrence in oncologic patients (1). Large BM can be defined according to their diameter or volume, with lesions measuring either $\geq 2$ or $\geq 3 \mathrm{~cm}$ in diameter or $\geq 4 \mathrm{~cm}^{3}$ (2-8) being considered in this category. The optimal treatment for these tumors has not yet been established. The combination of surgery with post operative radiation either to the cavity or to the whole brain (WBRT), SRS alone or hypofractionated radiation therapy (HFRT) have been proposed to address these tumors (3-16) However, local control (LC) rates of large brain metastasis are known to be inferior to those of smaller dimension $(4,5,14-20)$. When possible, surgery, with post operative radiation, should be considered (21) to decrease mass effect, alleviate neurological symptoms and facilitate management. For patients with large brain metastasis unable to undergo surgical resection, WBRT has been considered to be the standard of care. However, WBRT is associated with a poor local control for lesions of larger diameter (22). Nieder et al. (22) analyzed the efficacy of WBRT in controlling 336 brain metastasis in 108 patients. Local failure was estimated to be $48 \%$ in tumors measuring $<0.5 \mathrm{~cm}^{3}$; however, all lesions measuring $>10 \mathrm{~cm}^{3}$ recurred. Complete response was observed only in tumors measuring $<6.4 \mathrm{~cm}^{3}$ although partial response was seen in large or necrotic metastases.

Radiosurgery (SRS) is increasingly becoming the preferred treatment for BM, not only for its efficacy in providing good local control, but also for its limited long term toxicity profile, especially regarding neurocognitive function when compared to whole brain radiation therapy (WBRT) $(10,23,24)$. Moreover, the usage of SRS alone has not been linked to a decrease in OS (25). SRS alone is an effective treatment for smaller metastases. However, as tumor size increases, the dose that can be administered safely, without any neurological toxicity, decreases (26). In the dose escalation study RTOG 90-05 (27), lesions measuring $\leq 2,2.1-3$, and $3.1-4 \mathrm{~cm}$ were treated by radiosurgery with doses of 24, 18, and $15 \mathrm{~Gy}$, respectively. By using this fractionation scheme, Vogelbaum et al. (20) reported that, while treatment with radiosurgery achieved only a LC of 49 and $45 \%$ in lesions measuring $2.1-3 \mathrm{~cm}$ in diameter and $3.1-4 \mathrm{~cm}$, lesions measuring $\leq 2 \mathrm{~cm}$ achieved a $\mathrm{LC}$ of more than $85 \%$ when treated with a dose of $24 \mathrm{~Gy}$. The same conclusions were made by Elliott et al. (28) and Schoeggl et al. (29) where the treatment of lesions measuring $>10$ and $>17 \mathrm{~mm}$, respectively 
by radiosurgery had more local failure. Petrovich et al. (30) concluded that 1 year LC of lesions $<3 \mathrm{cc}$ was greater $(90 \%)$ when compared to that of lesions $>3 \mathrm{cc}(78 \%)$. Ebner et al. (15) concluded that lesions measuring $\geq 3 \mathrm{~cm}$ had a worse LC at 1 year (68\%) then lesions $<3 \mathrm{~cm}(86 \%)$. It has been speculated that better LC could possibly be achieved with a higher prescribed dose $(18,20,24,31)$. However, the administration of greater doses of radiation in one single fraction to a large volume is limited by the possibility of acute and late side effects and the dose to surrounding organs (OAR), for example the brainstem or optic nerves (32-34).

\section{OUTCOMES WITH HYPOFRACTIONATION FOR LARGE METASTASIS}

In an attempt to increase the biologically equivalent dose (BED) administered to BM and possibly LC while minimizing the risk of radiation induced toxicity, the administration of large doses of radiation in a few fractions (typically 2-6) has been studied $(7,12,13,16)$. Although this alternative to radiosurgery requires the patient to undergo multiple days of treatment, it has been associated with a median OS of 7-17 months and a 1 year LC of 64 to $100 \%$. $(3,6,7,12,13,16,35-42)$. In a review of 448 patients treated in eight series, it was concluded that HFRT can safely be administered in patients with lesions measuring $>1 \mathrm{~cm}$; furthermore, for tumors with a diameter $>2 \mathrm{~cm}$, HFRT seemed preferable to SRS, with LC of $68.2-93 \%$ and a low rate of radionecrosis of $3.1 \%$ (43).

Multiple studies have looked at the outcomes of patients treated with HFRT (Table 1). A prospective phase II study (36) evaluated the efficacy of HFRT in patients not amenable to SRS. Patients with lesions with a volume of $>3 \mathrm{cc}$ or located in eloquent area were considered. Median diameter of lesions treated was $2.27 \mathrm{~cm}$. Seventy-two patients received 5 treatments of $6 \mathrm{~Gy}$ if WBRT was given or $5 \mathrm{X} 7 \mathrm{~Gy}$ in patients treated singlehandedly with HFRT. Complete response was seen in $66 \%$ of patients, possibly because of the median gross tumor volume (GTV volume) measured at $6 \mathrm{cc}(0.29-65.57)$. Local control was deemed to be over $70 \% 1$ year after treatment. Size of the treated volume was associated with a 7 months disease specific survival (DDSS) of $81 \%$ for tumors $<6 \mathrm{cc}$ vs. $53 \%$ for lesions $\geq$ $6 \mathrm{cc}$ ). Inoue et al. (40) looked at 88 patients treated with large BM measuring $\geq 10 \mathrm{~cm}^{3}\left(10-74.6 \mathrm{~cm}^{3}\right)$. Tumors measuring $10-$ $19.9 \mathrm{~cm}^{3}$ received $27-30 \mathrm{gy}$ in three fractions $(\mathrm{fx})$; the majority received $31-35 \mathrm{~Gy}$ in $5 \mathrm{fx}$ for lesions $20-29.9 \mathrm{~cm}^{3}$ and $35-$ $42 \mathrm{~Gy}$ in $8-10 \mathrm{fx}$ was administered to those measuring $\geq 30$ $\mathrm{cm}^{3}$. Median single dose equivalent of the maximum dose was $46-48$ Gy. LC was seen in $90.2 \%$ of patients with no difference in LC, regardless of the volume treated. A study by Rajakesari et al. (41). retrospectively reviewed the outcomes of 112 patients treated with HFRT ( $87 \%$ received a dose of $25 \mathrm{~Gy}$ in $5 \mathrm{fx}$ ), 70 of which had brain metastasis measuring $>3 \mathrm{~cm}$. With a median follow up of 13.5 months, 1 year LC was 56\%. Navarria et al. (7) treated 102 patients with HFRT. In this study, 27 Gy in 3 daily $\mathrm{fx}$ was administered to 51 brain metastasis measuring $2.1-3 \mathrm{~cm}$; lesions of $3.1-5 \mathrm{c}$ in diameter received $32 \mathrm{~Gy}$ in 4 daily $\mathrm{fx}$. The fractionation was chosen to provide a biologically equivalent dose $\left(\mathrm{BEDGY}_{10}\right)>50 \mathrm{~Gy}$. With these fractionation schemes, lesions, irrespective of the dose administered, had a 1 year LC of $96 \%$.

\section{Srs vs. Hypofx}

Feuvret et al. (16) published the outcomes of 36 patients treated for solitary BM larger than $3 \mathrm{~cm}$ in diameter (median diameter $3.7 \mathrm{~cm}$ ), with either radiosurgery or HFRT. Patients in this case series received either $14 \mathrm{~Gy}$ in one fraction or 3 fractions of 7.7 Gy. One year LC rates differed between the two cohorts, with $100 \%$ of lesions treated with HFRT being controlled vs. $58 \%$ in patients treated with SRS. Moreover, no cases of radionecrosis were reported. Minniti et al. (12) confirmed these results in a retrospective study of patients treated with $\mathrm{BM}$ measuring $>2 \mathrm{~cm}$. A HFRT treatment of $27 \mathrm{~Gy}$ in $3 \mathrm{fx}$ was compared to a SRS in which tumors measuring $2-3 \mathrm{~cm}$ received $18 \mathrm{~Gy}$ and lesions measuring $\geq 3 \mathrm{~cm} 15-16 \mathrm{~Gy}$. One year LC rates were statistically different between the two groups, with $90 \%$ of patients treated with HFRT vs. $77 \%$ of patients treated with SRS attaining LC at 1 year (12).

\section{FACTORS INFLUENCING LOCAL CONTROL AND OVERALL SURVIVAL AFTER HFRT FOR LARGE METASTASES}

Multiples prognostic factors have been analyzed to assess OS and LC of brain metastases treated with HFRT (Table 2). However, none of the studied factors were predictive of OS or LC by all authors. Patient overall well-being, identified with the Karnofsky Performance Score (KPS) as well as the patient's recursive partitioning analysis (RPA) score seem to be predictive of overall survival in a number of studies $(3,7,12,13,36-38)$. Local control seems to be influenced by the dose administered and the size of the treated tumor, albeit not by all.

\section{MULTIPLE STAGES STEREOTACTIC RADIOSURGERY}

A possible alternative to single fraction SRS and hypofractionation for large brain metastasis is a planned multiple treatment radiosurgery over two or more sessions separated by weeks or months $(3,35,39,42)$. Higuchi et al. (39) published in 2009, a study involving 43 patients treated for BM measuring $\geq 10 \mathrm{~cm}^{3}$ with $30 \mathrm{~Gy}$ delivered in $3 \mathrm{fx}$ every 2 weeks. After delivery of 10 and $20 \mathrm{~Gy}$, a reduction in volume of $18.8 \%$ and almost $40 \%$, respectively, was noted in more than $90 \%$ of tumors. A 12 months LC of $75.9 \%$ was reported. Yomo and Hayashi (42) used a two stage treatment with radiation administered every 3-4 weeks. Fifty-eight BM with a volume of $>10 \mathrm{cc}$ were treated with a total of 20-30 Gy. One year LC of $64 \%$ was observed. Angelov et al. (3) reported results from 54 patients treated for $63 \mathrm{BM} \geq 2 \mathrm{~cm}$ in diameter with a total dose of 24-33 Gy (median 30 Gy) (BEDGy 10 : 44-73; median 62.5 Gy) in 2-3 fx to the target. Time between the first and second treatment was 1 month. Tumors were usually replanned before each treatment and volumes redefined. Analogous to the results 
TABLE 1 | Selected series of patients treated with HFRT.

\begin{tabular}{|c|c|c|c|c|c|c|c|}
\hline & $\begin{array}{l}\text { No of } \\
\text { Pts/BM }\end{array}$ & $\begin{array}{l}\text { Volume }\left(\mathrm{cm}^{3}\right) \\
\text { diameter }(\mathrm{cm}) \\
\text { (median) }\end{array}$ & $\begin{array}{l}\text { Median dose } \\
\text { [prescribed } \\
\text { isodose }(\%)]\end{array}$ & BEDGy $_{10}$ & $\begin{array}{l}\text { Median } 1 \text { year overall } \\
\text { survival (OS) } \\
\text { (months) }(\%)\end{array}$ & $\begin{array}{l}1 \text { year local } \\
\text { control } \\
\text { (LC) } \\
(\%)\end{array}$ & $\begin{array}{c}\text { Radionecrosis } \\
(\%)\end{array}$ \\
\hline Feuvret et al. (16) & $12 \mathrm{pts}$ & $\begin{array}{l}29.4 \mathrm{c} \mathrm{cm}^{3} \\
4.4 \mathrm{~cm}\end{array}$ & 3X7.7Gy to PTV & 39.4 & 504 days & $100 \%$ & None \\
\hline Fokas et al. (38) & $102 \mathrm{pts}$ & $\begin{array}{l}\text { Gr 1: } 2.04 \mathrm{~cm}^{3} \\
\text { Gr 2: } 5.93 \mathrm{~cm}^{3}\end{array}$ & $\begin{array}{l}\text { Gr.1 }(n=61): 7 \times 5 g y \\
\operatorname{Gr} 2(n=61): \\
10 X 4 G y\end{array}$ & $\begin{array}{l}\text { Gr 1: } 52.5 \\
\text { Gr 2: } 56\end{array}$ & $\begin{array}{l}\text { Gr 1: } 7 \mathrm{mo} \\
\text { Gr 2: } 10 \mathrm{mo}\end{array}$ & $\begin{array}{l}\text { Gr 1: } 75 \% \\
\text { Gr 2: } 71 \%\end{array}$ & 1 patient in Gr 1 \\
\hline Inoue et al. (40) & $\begin{array}{l}88 \mathrm{pts} / \\
92 \mathrm{BM}\end{array}$ & $16.2 \mathrm{c} \mathrm{cm}^{3}$ & $\begin{array}{l}\text { Gr 1: } 10-19.9 \mathrm{~cm}^{3} \text { : } \\
27-30 \text { Gy in } 3 \mathrm{fx} \\
\text { Gr 2: } 20-29.0 \mathrm{~cm}^{3} \text { : } \\
\text { 31-35 Gy in } 5 \mathrm{fx} \\
\text { Gr 3: }>30 \mathrm{~cm}^{3}: \\
\text { 35-42 Gy in } 8-10 \mathrm{fx} \\
(55-57 \%)\end{array}$ & $\begin{array}{l}\text { Gr 1: } 51.3-60 \\
\text { Gr 2: } 50.2-59.5 \\
\text { Gr 3: } 50.7-59.6\end{array}$ & $9 \mathrm{mo}$ & $\begin{array}{l}\text { Marginal } \\
\text { recurrences: } \\
\text { GR 1: } 7 \% \\
\text { Gr 2: } 11 \% \\
\text { Gr 3: } 0 \%\end{array}$ & \\
\hline Minniti et al. (12) & $138 \mathrm{pts}$ & $12.5 \mathrm{~cm}^{3}$ & $\begin{array}{l}27 \text { Gy in } 3 \mathrm{fx} \\
(80-90 \%)\end{array}$ & 51.3 & $\begin{array}{c}13.4 \text { months } \\
56 \%\end{array}$ & $\begin{array}{l}90 \% \text { (for lesions } \\
\geq 3 \mathrm{~cm} \mathrm{73 \% )}\end{array}$ & $\begin{array}{l}9 \% \text { for HFRT } \\
14 \% \text { for lesions } \\
>3 \mathrm{~cm}\end{array}$ \\
\hline Navarria et al. (7) & $\begin{array}{l}102 \text { pts } \\
51 \text { Gr } 1 \\
51 \text { Gr } 2\end{array}$ & $\begin{array}{l}16.3 \mathrm{~cm}^{3} \\
2.9 \mathrm{~cm}\end{array}$ & $\begin{array}{l}\text { Gr 1: diameter } 2.1-3 \\
\text { cm: } 27 \text { Gy in } 3 \mathrm{fx} \\
\text { Gr 2: diameter } 3.1-5 \\
\mathrm{~cm}: 32 \text { Gy in } 4 \mathrm{fx} \\
(80 \%)\end{array}$ & $\begin{array}{l}\text { Gr 1: } 51.3 \\
\text { Gr 2: } 57.6\end{array}$ & $\begin{array}{c}14 \mathrm{mo} \\
69 \% \\
\text { Gr } 1: 14 \mathrm{mo} \\
60 \% \\
\text { Gr } 2: 14 \mathrm{mo} \\
\quad 80 \%\end{array}$ & $\begin{array}{c}96 \% \\
\text { Gr } 1: 100 \% \\
\text { Gr } 2: 91 \%\end{array}$ & $5.8 \%$ \\
\hline Murai et al. (6) & $\begin{array}{l}54 \mathrm{pts} / \\
61 \mathrm{BM}\end{array}$ & $\geq 2.5 \mathrm{~cm}$ & $\begin{array}{l}\text { diameter } 2.5-3 \mathrm{~cm}: 3 \\
\mathrm{fx} \\
\text { diameter } \geq 4 \mathrm{~cm}: 5 \mathrm{fx} \\
\text { Gr } 1 \text { : } \\
\text { 18-22 Gy in } 3 \mathrm{fx} \\
21-25 \text { Gy in } 5 \mathrm{fx} \\
\text { Gr 2: } \\
22-27 \text { Gy in } 3 \mathrm{fx} \\
25-31 \text { Gy in } 5 \mathrm{fx} \\
\text { Gr } 3 \text { : } \\
27-30 \text { Gy in } 3 \mathrm{fx} \\
31-35 \text { Gy in } 5 \mathrm{fx}\end{array}$ & $\begin{array}{c}\text { Gr 1: } \\
28.8-39.4 \\
29.8-37.5 \\
\text { Gr 2: } \\
39-51.3 \\
37.5-50.2 \\
\text { Gr 3: } \\
51.3-60 \\
50.2-59.5\end{array}$ & $31 \%$ & $\begin{array}{c}69 \% \\
\text { Gr1: } 66 \% \\
\text { Gr 2: } 65 \% \\
\text { Gr 3: } 68 \%\end{array}$ & None \\
\hline $\begin{array}{l}\text { Rajakesari et al. } \\
(41)\end{array}$ & 70 pts & $1.7 \mathrm{~cm}$ & $\begin{array}{l}25 \text { Gy in } 5 \mathrm{fx} \\
(90-95 \%)\end{array}$ & 37.5 & $10.7 \mathrm{mo}$ & $56 \%$ & $4.3 \%$ \\
\hline Fahrig et al. (37) & $\begin{array}{l}150 \text { pts/ } \\
228 \text { BM } \\
\text { Gr 1: } 72 \\
\text { Gr 2: } 59 \\
\text { GR 3: } 97\end{array}$ & $6.1 \mathrm{~cm}^{3}$ & $\begin{array}{l}\text { Gr 1: 5X 6-7Gy } \\
\text { Gr 2: } 10 \times 4 \text { Gy } \\
\text { Gr 3: } 7 \times 5 \text { Gy } \\
(90 \%)\end{array}$ & $\begin{array}{c}\text { Gr 1: 48-59.5 Gy } \\
\text { Gr 2: } 56 \text { Gy } \\
\text { GR 3: } 52.5 \text { Gy }\end{array}$ & $\begin{array}{c}16 \mathrm{mo} \\
83 \% \\
\text { Gr 2 and Gr 3: } 17 \mathrm{mo} \\
\text { Gr 1: } 11 \mathrm{mo}\end{array}$ & $\begin{array}{l}\text { Gr 1: } 87 \% \\
\text { Gr 2: } 95 \% \\
\text { GR 3: } 96 \%\end{array}$ & $1.3 \%$ \\
\hline Aoyama et al. (44) & $\begin{array}{l}87 \mathrm{pts} / \\
159 \mathrm{BM}\end{array}$ & & $35 \mathrm{~Gy}$ in $4 \mathrm{fx}$ & 62.9 & $8.7 \mathrm{mo}$ & $81 \%$ & \\
\hline $\begin{array}{l}\text { Ernst-Stecken } \\
\text { et al. (36) }\end{array}$ & $\begin{array}{l}51 \mathrm{pts} / \\
72 \mathrm{BM}\end{array}$ & $\begin{array}{l}2.27 \mathrm{~cm} \\
6 \mathrm{~cm}^{3}\end{array}$ & $\begin{array}{l}\text { Gr 1: If WBRT prior: } \\
\text { 5X 6Gy } \\
\text { Gr 2: no WBRT: 5X } \\
7 \text { Gy } \\
(90 \%)\end{array}$ & $\begin{array}{l}\text { Gr 1: } 58 \\
\text { Gr2: } 59.5\end{array}$ & $11 \mathrm{mo}$ & $76 \%$ & $2 \%$ \\
\hline
\end{tabular}

(Continued) 


\begin{tabular}{|c|c|c|c|c|c|c|c|}
\hline & $\begin{array}{l}\text { No of } \\
\text { Pts/BM }\end{array}$ & $\begin{array}{l}\text { Volume }\left(\mathrm{cm}^{3}\right) \\
\text { diameter }(\mathrm{cm}) \\
\text { (median) }\end{array}$ & $\begin{array}{l}\text { Median dose } \\
\text { [prescribed } \\
\text { isodose (\%)] }\end{array}$ & BEDGy $_{10}$ & $\begin{array}{c}\text { Median } 1 \text { year overall } \\
\text { survival (OS) } \\
\text { (months) }(\%)\end{array}$ & $\begin{array}{l}1 \text { year local } \\
\text { control } \\
(\mathrm{LC}) \\
(\%)\end{array}$ & $\begin{array}{c}\text { Radionecrosis } \\
(\%)\end{array}$ \\
\hline \multicolumn{8}{|c|}{ MULTIPLE STAGE RADIOSURGERY SERIES } \\
\hline Higuchi et al. (39) & 43 pts & $17.8 \mathrm{~cm}^{3}$ & $\begin{array}{l}10 \text { Gy in } 3 \mathrm{fx}, \\
2 \text { weeks apart }\end{array}$ & 60 & $\begin{array}{l}8.8 \mathrm{mo} \\
76.2 \%\end{array}$ & $75.9 \%$ & None \\
\hline $\begin{array}{l}\text { Yomo and Hayashi } \\
\text { (42) }\end{array}$ & 58 pts & $16.4 \mathrm{~cm}^{3}$ & $\begin{array}{l}\text { 20-30 Gy in } 2 \text { fx; } \\
\text { 3-4 weeks apart } \\
(45 \%)\end{array}$ & $40-75$ & $\begin{array}{c}11.8 \mathrm{mo} \\
47 \%\end{array}$ & $64 \%$ & None \\
\hline Angelov et al. (3) & $\begin{array}{l}54 \mathrm{pts} / \\
63 \mathrm{BM}\end{array}$ & $\begin{array}{l}10.54 \mathrm{~cm}^{3} \\
3.3 \mathrm{~cm}\end{array}$ & $\begin{array}{l}30 \text { Gy in } 2 \mathrm{fx} \\
1 \text { months apart } \\
(54 \%)\end{array}$ & 75 & $\begin{array}{l}10.8 \\
49 \%\end{array}$ & 88\% (@6 mo) & $3.17 \%$ \\
\hline Dohm et al. (35) & $\begin{array}{l}33 \mathrm{pts} / \\
39 \mathrm{BM}\end{array}$ & $11.68 \mathrm{~cm}^{3}$ & $\begin{array}{l}15 \text { Gy in } 1 \mathrm{fx} \text { followed } \\
\text { a month later by } \\
14 \text { Gy in } 1 \mathrm{fx} \\
(50 \%)\end{array}$ & $37.5-33.6$ & $60 \%$ & $87 \%$ & $10.2 \%$ \\
\hline
\end{tabular}

published by Higuchi, they noted a median decrease in tumor volume of $17 \%$; $90 \%$ of the lesions showed no progression with $67 \%$ of lesions showing a decrease in volume of $\geq 30$ and $24 \%$ remaining stable. At 6 months follow up, LC was $88 \%$. Dohm et al. (35) reported the results of 33 patients treated for 39 lesions in 2 treatments separated by 4 weeks. A median dose of $15 \mathrm{~Gy}$ (10-21 Gy) and 14 Gy (10-18 Gy) were administered on first and second treatment, respectively. One year local failure was $13 \%$. Median volume reduction after first treatment was $32.6 \%$ and was observed in 33 tumors.

\section{DOSE TO TARGET VOLUMES AND ORGANS AT RISK (OAR)}

In the treatment of $\mathrm{BM}$ with a single radiosurgery treatment, most radiation oncologists will prescribe doses in keeping with RTOG 90-05 (26); larger brain metastases, with a diameter of 3$4 \mathrm{~cm}$, would therefore receive a single dose of $15 \mathrm{~Gy}$. However, for these tumors, LC rates at 12 months are suboptimal, ranging from 37 to $62 \%(18,26,27)$. Vogelbaum et al. (20) published results from more than 200 patients that received radiosurgery in a single fraction. Although the results were similar to the ones previously stated, LC was deemed to be $45-49 \%$ when lesions received $15-18$ Gy, but increased to $85 \%$ when 24 Gy was administered. However, doses of $24 \mathrm{~Gy}$ have been associated with a higher risk of CNS toxicity, of which the most feared is radionecrosis (26).

One of the advantages of hypofractionation is the delivery of a higher BED while minimizing the risk of side effects to the surrounding OAR. Nevertheless, the optimal dose to administer is not known. In the literature, multiple fractionation schemes have been studied (Table 1). Most use a minimum of $4 \mathrm{~Gy}$ and a maximum of $10 \mathrm{~Gy}$ per fraction. A total BEDGy 10 of at least $50 \mathrm{~Gy}$ seems to provide better local control (38). Marcrom et al. (45) compared a dose of $25 \mathrm{~Gy}$ in $5 \mathrm{fx}$ to $30 \mathrm{~Gy}$ in $5 \mathrm{fx}$ in 72 patients treated for $182 \mathrm{BM}$ measuring up to $5.5 \mathrm{~cm}$ (39 cc); 36 lesions being $\geq 3 \mathrm{~cm}$ in diameter. A total dose of $30 \mathrm{~Gy}$ was associated with a better LC 1 year after treatment (72 vs. $40 \%$ for lesions receiving $25 \mathrm{~Gy}$ ). Fahrig et al. (37) assessed three different doses to $\mathrm{BM}$ with a maximal diameter $>3 \mathrm{~cm}$. Patients received either $5 \mathrm{fx}$ of 6-7 Gy (total: 30-35 Gy) in group 1, $10 \mathrm{fx}$ of $4 \mathrm{~Gy}$ (total $40 \mathrm{~Gy}$ ) in group 2 or $7 \mathrm{fx}$ of $5 \mathrm{~Gy}$ (total $35 \mathrm{~Gy}$ ) in group 3. Of these three regiments, the last two seemed to provide better 1 year LC and median OS when compared to group 1. This difference in OS between the three groups could possibly be explained by the fact that there were significantly less patients with RPA class I in group 1. CNS toxicity was deemed to be lesser for patients in group 2. On the other hand, a dose escalation study administering doses ranging from $18-22$ Gy in $3 \mathrm{fx}$ to $31-35$ Gy in $5 \mathrm{fx}$ did not demonstrate any difference in local control or overall survival in patients (6).

\section{Dose to OAR}

Although the optimal doses to be administered to the brain metastasis are not known, dose constraints to be applied to nearby critical organs (OAR) are less controversial. Maximum doses have been limited to $21-25$ Gy in $5 \mathrm{fx}$ or $15-18$ Gy in 3 $\mathrm{fx}(40,45,46)$ for the optical apparatus and to $31 \mathrm{~Gy}$ in $5 \mathrm{fx}$ or $23 \mathrm{~Gy}$ in $3 \mathrm{fx}$ for the brainstem $(45,46)$. Other possible dose limits that have been described for the brainstem are D1\% (dose administered to $1 \%$ of the volume) $\leq 20 \mathrm{~Gy}$ or V26Gy (volume of the brainstem receiving $26 \mathrm{~Gy})<1 \mathrm{cc}, \mathrm{D} 1 \% \leq 15 \mathrm{~Gy}$ or V20Gy (volume receiving $20 \mathrm{~Gy}$ ) $<0.2 \mathrm{cc}$ for the optical nerves and D1\% $<1 \mathrm{~Gy}$ for the lenses $(7,45)$. Maintaining a V14Gy $<3 \mathrm{~cm}^{3}$ for the brain parenchyma and $<1 \mathrm{~cm}^{3}$ for critical areas such as motor cortex, basal ganglia or thalamus has been described (40).

\section{POST OPERATIVE TREATMENT OF LARGE CAVITIES}

\section{Cyst Aspiration}

Tumor size can influence the local control of brain metastases and overall survival of patients as stated above. It can therefore be of interest to reduce their volume prior to radiation treatment, 
TABLE 2 | Selected series with factors influencing OS and local control in patient treated with HFRT.

\begin{tabular}{|c|c|c|c|c|}
\hline & \multicolumn{2}{|c|}{ Overall survival } & \multicolumn{2}{|c|}{ Local control } \\
\hline Inoue et al. (40) & $\begin{array}{l}\text { Lower survival for lesions } \geq 30 \\
\mathrm{~cm}^{3}\end{array}$ & & & $\begin{array}{l}\text { On UVA and MVA: } \\
\text { - Age } \\
\text { - Gender } \\
\text { - Tumor location within brain } \\
\text { - Tumor volume } \\
\text { - Number of fraction of RT } \\
\text { - V14 } \\
\text { - Tumor size: } 10-19.9 \mathrm{~cm}^{3} \text { vs. } \\
20-29.9 \mathrm{~cm}^{3} \text { vs. } \geq 30 \mathrm{~cm}^{3}\end{array}$ \\
\hline Fokas et al. (38) & $\begin{array}{l}\text { UVA: } \\
\text { - Chemotherapy status } \\
\text { (yes vs. no) } \\
\text { - RPA class: I vs. II-III } \\
\text { - Single BM (vs. multiple BM) } \\
\text { - Presence of extracerebral } \\
\text { disease } \\
\text { MVA: } \\
\text { RPA class I }\end{array}$ & $\begin{array}{l}\text { - Surgical resection } \\
\text { status } \\
\text { - Age } \\
\text { - Gender }\end{array}$ & $\begin{array}{l}\text { Dose administered } \\
\text { (srs vs. } 7 X \text { Xgy vs. } 10 X \\
4 \text { gy) }\end{array}$ & \\
\hline Jiang et al. (13) & $\begin{array}{l}\text { - Controlled primary tumor } \\
\text { - } \mathrm{KPS} \geq 80\end{array}$ & $\begin{array}{l}\text { - Gender } \\
\text { - Age } \\
\text { - Number of brain } \\
\text { mets } \\
\text { - } \text { presence of } \\
\text { extracranial disease } \\
\text { - RPA class }\end{array}$ & & $\begin{array}{l}\text { - } \text { Gender } \\
\text { - } \text { Age } \\
\text { - } \text { number of brain mets } \\
\text { - } \text { presence of extracranial } \\
\text { metastasis } \\
\text { - } \text { KPS } \\
\text { - RPA class }\end{array}$ \\
\hline Navarria et al. (7) & $\begin{array}{l}\text { UVA and MVA: } \\
\text { - KPS } \\
\text { - Extracranial disease (stable) }\end{array}$ & & $\begin{array}{l}\text { UVA and MVA: } \\
\text { - Gender } \\
\text { - Age } \\
\text { - KPS } \\
\text { - Histology } \\
\text { - Presence of } \\
\text { extracranial disease } \\
\text { - RPA-GPA class } \\
\text { - Tumor size }\end{array}$ & \\
\hline $\begin{array}{l}\text { Yomo and Hayashi } \\
\text { (42) }\end{array}$ & $\begin{array}{l}\text { - Extracranial disease (stable) } \\
\text { - Interval from cancer diagnosis } \\
\text { to RT treatment (<12 vs. > } \\
12 \text { months) } \\
\text { - Single vs. multiple BM }\end{array}$ & $\begin{array}{l}\text { - Age ( } \leq 65 \text { vs. }>65) \\
\text { - } \mathrm{KPS} \geq 90\end{array}$ & & \\
\hline Fahrig et al. (37) & $\begin{array}{l}\text { MVA: } \\
\text { - RPA class }\end{array}$ & $\begin{array}{l}\text { MVA: } \\
\text { - RT dose (5 X } 7 \text { Gy vs. } \\
\text { 10X 4Gy vs. } 7 \text { X5gy) }\end{array}$ & $\begin{array}{l}\text { Trend for better LC for } \\
\text { lesions treated with } \\
\text { 5X6-7Gy and 7X5Gy } \\
\text { vs. 10X4Gy }\end{array}$ & \\
\hline
\end{tabular}




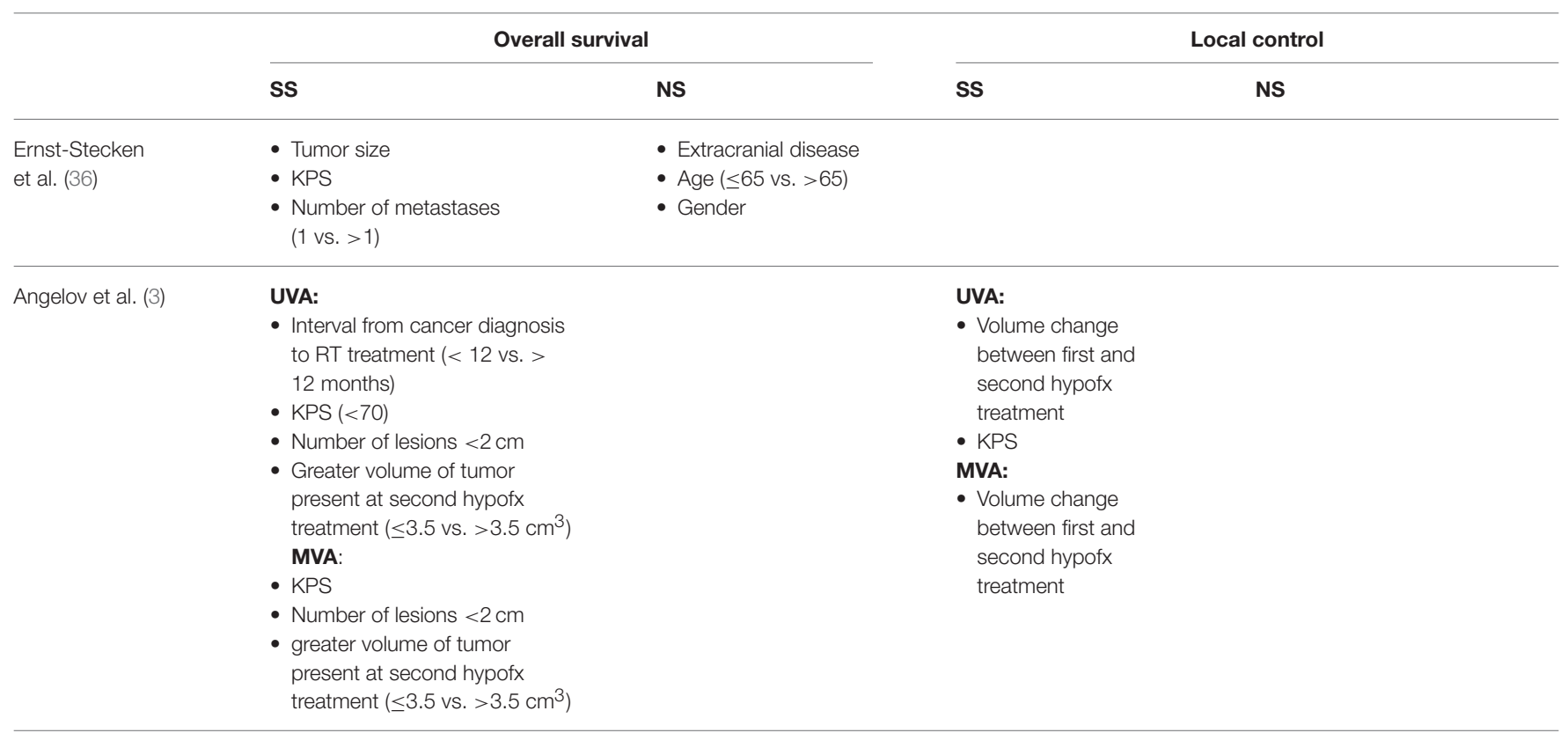

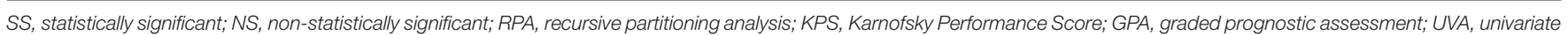
analysis; MVA, multivariate analysis; BM, brain metastasis.

permitting the administration of a higher radiation dose. An option for size reduction of cystic lesions is cyst aspiration, where a substantial decrease in tumor volume has been reported (47-50) (50.8-77.9\%). This could potentially allow for treatment with a higher radiation dose (48). By combining this method to adjuvant radiation, better local control can be obtained, ranging from 45.8 to $63 \%(47-50)$. The latter also allows for the relief of acute symptoms related to mass effect $(51,52)$.

\section{Surgical Resection}

As previously mentioned, surgery should be considered for the treatment of large brain metastases. Post operatively, cavities can easily have a diameter $>3-4 \mathrm{~cm}$, rendering a radiosurgery treatment difficult. Larger cavities are thus usually treated with a hypofractionated treatment with doses ranging from $24 \mathrm{~Gy}$ in 3 fractions to $36 \mathrm{~Gy}$ in 6 fractions (53-56). Most studies published have used a planning tumor volume (PTV) of 2-3 mm (57-59). With most failures occurring within the surgical cavities (60), a PTV margin of 2-3 mm seems to be sufficient.

The treatment of surgical cavities with fractionated radiation confers good local control, ranging from 77 to $93 \%(2,12,54$, $61,62)$ in the literature. Moreover, local control of larger cavities does not appear to be associated with the number of fractions or dose used (63). Histology of the primary, does not seem to influence recurrence, with similar local control for radiosensitive (i.e., breast and lung up to 94\%) and radioresistant tumors [up to $90 \%$ i.e., melanoma, renal cell carcinoma $(2,12)]$ reported. Median survival after surgery and hypofractionated radiation treatment to cavities of large metastasis is $5.5-17$ months $(2,11$, $12,60,61,64)$. A possible advantage of WBRT over HFRT in the post operative setting is the risk of leptomeningeal disease.
The rate of leptomeningeal spread to meninges and cerebrospinal fluid in patients treated with WBRT is $5-12 \%(65,66)$ vs. $14-28 \%$ $(66,67)$.

\section{ADVERSE EFFECTS}

In the setting of hypofractionation, the rate of radiation necrosis has been estimated to be up to $10-15 \%(3,6,7,11,12,16,35-$ 42). Authors have tried to determine dosimetric parameters and tumor characteristics that could possibly predict the risk of radionecrosis and severe CNS toxicity. In series comparing the usage of SRS vs. HFRT for the treatment of metastases, the rate of radionecrosis seems to be higher when patients are treated with a single fraction. Data (12) has showed that large tumors treated with $9 \mathrm{~Gy}$ in $3 \mathrm{fx}$ had a $14 \%$ risk of radionecrosis vs. $33 \%$ for lesions treated in a single fraction. The risk of $\mathrm{RN}$ when treated with 3 fractions seems to be related to the volume receiving $18 \mathrm{~Gy}(12)$. Rates of radionecrosis are estimated to be $5 \%$ for $\mathrm{V} 18 \leq 30.2 \mathrm{~cm}^{3}$ and up to $14 \%$ for $\mathrm{V} 18>30 \mathrm{~cm}^{3}$ (12). When analyzed according to quartile distribution, the risk was estimated to be: $0,6,13$, and $24 \%$ for V18 < 22.8, 22.8-30.2, $30.3-41.2$, and $>41.2 \mathrm{~cm}^{3}$, respectively (12). Others, Inoue et al. (40) have found that the surrounding brain volume treated to the equivalent of a single dose of $14 \mathrm{~Gy}$ (V14Gy) can be predictive of the risk of radionecrosis, with $\mathrm{V} 14 \geq 7.0 \mathrm{~cm}^{3}$ being a risk factor for developing extensive brain oedema and RN. It has been concluded that the risk of $\mathrm{RN}$ can be maintained under $2-15 \%$ when a BED of $90-127 \mathrm{~Gy} 3(\alpha / \beta=3)$ is used (dose of $24-35$ Gy in $3-5 \mathrm{fx})(12,36)$. Size has also been reported as a possible culprit, however inconsistently, with lesions of $>3 \mathrm{~cm}$ at a higher risk (45). 
Neurological symptoms related to HFRT has been reported in patients necessitating long term steroid treatment $(13,35$, 36). Deaths secondary to surrounding oedema and the presence of radionecrosis, although rare, have also been described (13). Toxicity of lesser severity (grade 1-3) (according to the National Cancer Institute Common Terminology Criteria for Adverse Events $v .3$ and $v .4)$ has been reported in $2-52 \%(12,16,36,38)$ of patients treated with HFRT. Age $(>60)$, treatment with less than five fractions, and a greater treated volume (possibly of $>20 \mathrm{~cm}^{3}$ ) $(36,40)$ have been suggested to be predictive of brain oedema necessitating steroids. Lesions located deep within the white matter are perhaps more likely to cause oedema necessitating corticosteroids, and it has been suggested for these to keep V14Gy to $\leq 3 \mathrm{~cm}^{3}$ (40).

\section{PLANNING FOR RADIATION THERAPY}

Planning of a hypofractionated radiation treatment for large brain metastases is very similar to that of a radiosurgery treatment. Patients usually undergo a planning CT and a highfield 3D distortion corrected T1 contrast MRI with isotropic voxels $\leq 1 \mathrm{~m}$ MRI with gadolinium to help delineate tumor volumes. Gross target volume (GTV) is delineated on CT scan and MRI and is defined as the area of contrast enhancement. Clinical target volume (CTV) is usually not defined in the treatment of brain metastasis treated with upfront radiation. However, in post operative treatment, it is defined as any contrast enhancing post operative changes on planning MRI and does usually not include the surgical tract $(65,68)$. In

\section{REFERENCES}

1. Soffietti R, Ruda R, Trevisan E. Brain metastases: current management and new developments. Curr Opin Oncol. (2008) 20:676-84. doi: 10.1097/CCO.0b013e32831186fe

2. Choi CY, Chang SD, Gibbs IC, Adler JR, Harsh GR IV, Atalar B. What is the optimal treatment of large brain metastases? An argument for a multidisciplinary approach. Int J Radiat Oncol Biol Phys. (2012) 84:688-93. doi: 10.1016/j.ijrobp.2012.01.028

3. Angelov L, Mohammadi AM, Bennett EE, Abbassy M, Elson P, Chao ST, et al. Impact of 2-staged stereotactic radiosurgery for treatment of brain metastases $\geq 2$ cm. J Neurosurg. (2017) 129:366-82. doi: 10.3171/2017.3.JNS162532

4. Han JH, Kim DG, Chung HT, Paek SH, Park CK, Jung HW. Radiosurgery for large brain metastases. Int J Radiat Oncol Biol Phys. (2012) 83:113-20. doi: 10.1016/j.ijrobp.2011.06.1965

5. Lee CC, Yen CP, Xu Z, Schlesinger D, Sheehan J. Large intracranial metastatic tumors treated by Gamma Knife surgery: outcomes and prognostic factors. $J$ Neurosurg. (2014) 120:52-9. doi: 10.3171/2013.9.JNS131163

6. Murai T, Ogino H, Manabe Y, Iwabuchi M, Okumura T, Matsushita Y, et al. Fractionated stereotactic radiotherapy using CyberKnife for the treatment of large brain metastases: a dose escalation study. Clin Oncol. (2014) 26:151-8. doi: 10.1016/j.clon.2013.11.027

7. Navarria P, Pessina F, Cozzi L, Ascolese AM, De Rose F, Fogliata A, et al. Hypofractionated stereotactic radiotherapy alone using volumetric modulated arc therapy for patients with single, large brain metastases unsuitable for surgical resection. Radiat Oncol. (2016) 11:76. doi: 10.1186/s13014-016-0653-3

8. Sneed PK, Suh JH, Goetsch SJ, Sanghavi SN, Chappell R, Buatti JM, et al. A multi-institutional review of radiosurgery alone vs. radiosurgery with whole brain radiotherapy as the initial management of brain metastases. Int J Radiat Oncol Biol Phys. (2002) 53:519-26. doi: 10.1016/S0360-3016(02)02770-0 both situations, surrounding oedema is usually not included in treatment volumes. Planning tumor volume (PTV) is defined by adding a geometric margin of $1-3 \mathrm{~mm}(6,7,16,24,36)$. Treatment can be administered using different delivery systems and is usually linear-accelerator based to avoid head frame fixation as patients are usually treated with multiple fractions. However, treatments with dedicated intracranial radiosurgery unit such as the Gamma Knife have been published, especially in the setting for multi-staged treatment administered weeks apart $(3,42)$.Treatments can be delivered using multiple conformal arcs, static field IMRT or a dedicated radiosurgery unit such as CyberKnife ${ }^{\circledR}$. As with any high dose per fraction treatment, image guidance is a must and has to be performed daily for patient set up and positioning verification.

\section{CONCLUSIONS}

Hypofractionated radiation therapy treatment is a viable alternative to WBRT for the upfront treatment of brain metastasis that are not amenable to radiosurgery or surgery, or in the postoperative setting. It is associated with an accepted toxicity profile and good local control of lesions. The optimal dose fractionation is however still unknown and necessitates further investigation.

\section{AUTHOR CONTRIBUTIONS}

The author confirms being the sole contributor of this work and has approved it for publication.
9. Mehta MP, Tsao MN, Whelan TJ, Morris DE, Hayman JA, Flickinger JC, et al. The American Society for Therapeutic Radiology and Oncology (ASTRO) evidence-based review of the role of radiosurgery for brain metastases. Int $\mathrm{J}$ Radiat Oncol Biol Phys. (2005) 63:37-46. doi: 10.1016/j.ijrobp.2005.05.023

10. Brown PD, Jaeckle K, Ballman KV, Farace E, Cerhan JH, Anderson $\mathrm{SK}$, et al. Effect of radiosurgery alone vs radiosurgery with whole brain radiation therapy on cognitive function in patients with 1 to 3 brain metastases: a randomized clinical trial. JAMA (2016) 316:401-9. doi: 10.1001/jama.2016.9839

11. Jeong WJ, Park JH, Lee EJ, Kim JH, Kim CJ, Cho YH. Efficacy and safety of fractionated stereotactic radiosurgery for large brain metastases. J Korean Neurosurg Soc. (2015) 58:217-24. doi: 10.3340/jkns.2015.58.3.217

12. Minniti G, D’Angelillo RM, Scaringi C, Trodella LE, Clarke E, Matteucci P, et al. Fractionated stereotactic radiosurgery for patients with brain metastases. J Neurooncol. (2014) 117:295-301. doi: 10.1007/s11060-014-1388-3

13. Jiang XS, Xiao JP, Zhang Y, Xu YJ, Li XP, Chen XJ, et al. Hypofractionated stereotactic radiotherapy for brain metastases larger than three centimeters. Radiat Oncol. (2012) 7:36. doi: 10.1186/1748-717X-7-36

14. Ogura K, Mizowaki T, Ogura M, Sakanaka K, Arakawa Y, Miyamoto S, et al. Outcomes of hypofractionated stereotactic radiotherapy for metastatic brain tumors with high risk factors. J Neurooncol. (2012) 109:425-32. doi: 10.1007/s11060-012-0912-6

15. Ebner D, Rava P, Gorovets D, Cielo D, Hepel JT. Stereotactic radiosurgery for large brain metastases. J Clin Neurosci. (2015) 22:1650-4. doi: 10.1016/j.jocn.2015.05.019

16. Feuvret L, Vinchon S, Martin V, Lamproglou I, Halley A, Calugaru V, et al. Stereotactic radiotherapy for large solitary brain metastases. Cancer Radiother. (2014) 18:97-106. doi: 10.1016/j.canrad.2013.12.003

17. Baschnagel AM, Meyer KD, Chen PY, Krauss DJ, Olson RE, Pieper DR, et al. Tumor volume as a predictor of survival and local control in patients with 
brain metastases treated with Gamma Knife surgery. J Neurosurg. (2013) 119:1139-44. doi: 10.3171/2013.7.JNS13431

18. Molenaar R, Wiggenraad R, Verbeek-de Kanter A, Walchenbach R, Vecht C. Relationship between volume, dose and local control in stereotactic radiosurgery of brain metastasis. $\mathrm{Br} J$ Neurosurg. (2009) 23:170-8. doi: 10.1080/02688690902755613

19. Sheehan JP, Sun MH, Kondziolka D, Flickinger J, Lunsford LD. Radiosurgery for non-small cell lung carcinoma metastatic to the brain: long-term outcomes and prognostic factors influencing patient survival time and local tumor control. J Neurosurg. (2002) 97:1276-81. doi: 10.3171/jns.2002.97.6.1276

20. Vogelbaum MA, Angelov L, Lee SY, Li L, Barnett GH, Suh JH. Local control of brain metastases by stereotactic radiosurgery in relation to dose to the tumor margin. J Neurosurg. (2006) 104:907-12. doi: 10.3171/jns.2006.104.6.907

21. Patchell RA, Tibbs PA, Regine WF, Dempsey RJ, Mohiuddin M, Kryscio RJ, et al. Postoperative radiotherapy in the treatment of single metastases to the brain: a randomized trial. JAMA (1998) 280:1485-9. doi: 10.1001/jama.280.17.1485

22. Nieder C, Berberich W, Schnabel K. Tumor-related prognostic factors for remission of brain metastases after radiotherapy. Int J Radiat Oncol Biol Phys. (1997) 39:25-30. doi: 10.1016/S0360-3016(97)00154-5

23. Chang EL, Wefel JS, Hess KR, Allen PK, Lang FF, Kornguth DG, et al. Neurocognition in patients with brain metastases treated with radiosurgery or radiosurgery plus whole-brain irradiation: a randomised controlled trial. Lancet Oncol. (2009) 10:1037-44. doi: 10.1016/S1470-2045(09)70263-3

24. Aoyama H, Tago M, Kato N, Toyoda T, Kenjyo M, Hirota S, et al. Neurocognitive function of patients with brain metastasis who received either whole brain radiotherapy plus stereotactic radiosurgery or radiosurgery alone. Int J Radiat Oncol Biol Phys. (2007) 68:1388-95. doi: 10.1016/j.ijrobp.2007.03.048

25. Aoyama H, Shirato H, Tago M, Nakagawa K, Toyoda T, Hatano K, et al. Stereotactic radiosurgery plus whole-brain radiation therapy vs stereotactic radiosurgery alone for treatment of brain metastases: a randomized controlled trial. JAMA (2006) 295:2483-91. doi: 10.1001/jama.295.21.2483

26. Shaw E, Scott C, Souhami L, Dinapoli R, Kline R, Loeffler J, et al. Single dose radiosurgical treatment of recurrent previously irradiated primary brain tumors and brain metastases: final report of RTOG protocol 90-05. Int J Radiat Oncol Biol Phys. (2000) 47:291-8. doi: 10.1016/S0360-3016(99)00507-6

27. Shaw E, Scott C, Souhami L, Dinapoli R, Bahary JP, Kline R, et al. Radiosurgery for the treatment of previously irradiated recurrent primary brain tumors and brain metastases: initial report of radiation therapy oncology group protocol (90-05). Int J Radiat Oncol Biol Phys. (1996) 34:647-54. doi: 10.1016/0360-3016(95)02106-X

28. Elliott RE, Rush SC, Morsi A, Mehta N, Spriet J, Narayana A, et al. Local control of newly diagnosed and distally recurrent, low-volume brain metastases with fixed-dose (20 gy) gamma knife radiosurgery. Neurosurgery (2011) 68:921-31; discussion 31. doi: 10.1227/NEU.0b013e318208f58e

29. Schoeggl A, Kitz K, Ertl A, Reddy M, Bavinzski G, Schneider B. Prognostic factor analysis for multiple brain metastases after gamma knife radiosurgery: results in 97 patients. J Neurooncol. (1999) 42:169-75. doi: 10.1023/A:1006110631704

30. Petrovich Z, Yu C, Giannotta SL, O'Day S, Apuzzo ML. Survival and pattern of failure in brain metastasis treated with stereotactic Gamma knife radiosurgery. J Neurosurg. (2002) 97:499-506. doi: 10.3171/jns.2002.97.supplement

31. Mohammadi AM, Schroeder JL, Angelov L, Chao ST, Murphy ES, Yu JS, et al. Impact of the radiosurgery prescription dose on the local control of small (2 cm or smaller) brain metastases. J Neurosurg. (2017) 126:735-43. doi: 10.3171/2016.3.JNS153014

32. Mayo C, Martel MK, Marks LB, Flickinger J, Nam J, Kirkpatrick J. Radiation dose-volume effects of optic nerves and chiasm. Int J Radiat Oncol Biol Phys. (2010) 76:S28-35. doi: 10.1016/j.ijrobp.2009.07.1753

33. Mayo C, Yorke E, Merchant TE. Radiation associated brainstem injury. Int $J$ Radiat Oncol Biol Phys. (2010) 76:S36-41. doi: 10.1016/j.ijrobp.2009.08.078

34. Tishler RB, Loeffler JS, Lunsford LD, Duma C, Alexander E III, Kooy HM, et al. Tolerance of cranial nerves of the cavernous sinus to radiosurgery. Int J Radiat Oncol Biol Phys. (1993) 27:215-21. doi: 10.1016/0360-3016(93) 90230-S

35. Dohm A, McTyre ER, Okoukoni C, Henson A, Cramer CK, LeCompte MC, et al. Staged stereotactic radiosurgery for large brain metastases: local control and clinical outcomes of a one-two punch technique. Neurosurgery (2017) 83:114-21. doi: 10.1093/neuros/nyx355

36. Ernst-Stecken A, Ganslandt O, Lambrecht U, Sauer R, Grabenbauer G. Phase II trial of hypofractionated stereotactic radiotherapy for brain metastases: results and toxicity. Radiother Oncol. (2006) 81:18-24. doi: 10.1016/j.radonc.2006.08.024

37. Fahrig A, Ganslandt O, Lambrecht U, Grabenbauer G, Kleinert G, Sauer R, et al. Hypofractionated stereotactic radiotherapy for brain metastases-results from three different dose concepts. Strahlenther Onkol. (2007) 183:625-30. doi: 10.1007/s00066-007-1714-1

38. Fokas E, Henzel M, Surber G, Kleinert G, Hamm K, Engenhart-Cabillic R. Stereotactic radiosurgery and fractionated stereotactic radiotherapy: comparison of efficacy and toxicity in 260 patients with brain metastases. $J$ Neurooncol. (2012) 109:91-8. doi: 10.1007/s11060-012-0868-6

39. Higuchi Y, Serizawa T, Nagano O, Matsuda S, Ono J, Sato M, et al. Threestaged stereotactic radiotherapy without whole brain irradiation for large metastatic brain tumors. Int J Radiat Oncol Biol Phys. (2009) 74:1543-8. doi: 10.1016/j.ijrobp.2008.10.035

40. Inoue HK, Sato H, Suzuki Y, Saitoh J, Noda SE, Seto K, et al. Optimal hypofractionated conformal radiotherapy for large brain metastases in patients with high risk factors: a single-institutional prospective study. Radiat Oncol. (2014) 9:231. doi: 10.1186/s13014-014-0231-5

41. Rajakesari S, Arvold ND, Jimenez RB, Christianson LW, Horvath MC, Claus EB, et al. Local control after fractionated stereotactic radiation therapy for brain metastases. J Neurooncol. (2014) 120:339-46. doi: 10.1007/s11060-014-1556-5

42. Yomo S, Hayashi M. A minimally invasive treatment option for large metastatic brain tumors: long-term results of two-session Gamma Knife stereotactic radiosurgery. Radiat Oncol. (2014) 9:132. doi: 10.1186/1748-717X-9-132

43. Schlienger M, Nataf F, Huguet F, Pene F, Foulquier JN, Orthuon A, et al. [Hypofractionated stereotactic radiotherapy for brain metastases]. Cancer Radiother. (2010) 14:119-27. doi: 10.1016/j.canrad.2009.10.004

44. Aoyama H, Shirato H, Onimaru R, Brown PD, Chiang VLS, Kirkpatrick JP, et al. Hypofractionated stereotactic radiotherapy alone without wholebrain irradiation for patients with solitary and oligo brain metastasis using noninvasive fixation of the skull. Int J Radiat Oncol Biol Phys. (2003) 56:793800. doi: 10.1016/S0360-3016(03)00014-2

45. Marcrom SR, McDonald AM, Thompson JW, Popple RA, Riley KO, Markert JM, et al. Fractionated stereotactic radiation therapy for intact brain metastases. Adv Radiat Oncol. (2017) 2:564-71. doi: 10.1016/j.adro.2017.07.006

46. Timmerman RD. An overview of hypofractionation and introduction to this issue of seminars in radiation oncology. Semin Radiat Oncol. (2008) 18:215-22. doi: 10.1016/j.semradonc.2008.04.001

47. Ebinu JO, Lwu S, Monsalves E, Arayee M, Chung C, Laperriere NJ, et al. Gamma knife radiosurgery for the treatment of cystic cerebral metastases. Int J Radiat Oncol Biol Phys. (2013) 85:667-71. doi: 10.1016/j.ijrobp.2012.06.043

48. Franzin A, Vimercati A, Picozzi P, Serra C, Snider S, Gioia L, et al. Stereotactic drainage and Gamma Knife radiosurgery of cystic brain metastasis. I Neurosurg. (2008) 109:259-67. doi: 10.3171/JNS/2008/109/8/0259

49. Higuchi F, Kawamoto S, Abe Y, Kim P, Ueki K. Effectiveness of a 1day aspiration plus Gamma Knife surgery procedure for metastatic brain tumor with a cystic component. J Neurosurg. (2012) 117(Suppl.):17-22. doi: 10.3171/2012.7.GKS121001

50. Park WH, Jang IS, Kim CJ, Kwon DH. Gamma knife radiosurgery after stereotactic aspiration for large cystic brain metastases. J Korean Neurosurg Soc (2009) 46:360-4. doi: 10.3340/jkns.2009.46.4.360

51. Li Y, Xu D, Zhang Z, Zhang Y, Liu D, Liu X, et al. Gamma Knife surgery for brainstem metastases. J Neurosurg 2012;117 Suppl:13-6.

52. Liu X, Yu Q, Zhang Z, Zhang Y, Li Y, Liu D, et al. Same-day stereotactic aspiration and Gamma Knife surgery for cystic intracranial tumors. J Neurosurg. (2012) 117(Suppl.):45-8. doi: 10.3171/2012.7.GKS1 21019

53. Barnholtz-Sloan JS, Sloan AE, Davis FG, Vigneau FD, Lai P, Sawaya RE. Incidence proportions of brain metastases in patients diagnosed (1973 to 2001) in the Metropolitan Detroit Cancer Surveillance System. J Clin Oncol. (2004) 22:2865-72. doi: 10.1200/JCO.2004.12.149 
54. Connolly EP, Mathew M, Tam M, King JV, Kunnakkat SD, Parker $\mathrm{EC}$, et al. Involved field radiation therapy after surgical resection of solitary brain metastases-mature results. Neuro Oncol. (2013) 15:589-94. doi: 10.1093/neuonc/nos328

55. Hartford AC, Paravati AJ, Spire WJ, Li Z, Jarvis LA, Fadul CE, et al. Postoperative stereotactic radiosurgery without whole-brain radiation therapy for brain metastases: potential role of preoperative tumor size. Int J Radiat Oncol Biol Phys. (2013) 85:650-5. doi: 10.1016/j.ijrobp.2012.05.027

56. Hwang SW, Abozed MM, Hale A, Eisenberg RL, Dvorak T, Yao K, et al. Adjuvant Gamma Knife radiosurgery following surgical resection of brain metastases: a 9-year retrospective cohort study. J Neurooncol. (2010) 98:77-82. doi: 10.1007/s11060-009-0051-x

57. Luther N, Kondziolka D, Kano H, Mousavi SH, Engh JA, Niranjan A, et al. Predicting tumor control after resection bed radiosurgery of brain metastases. Neurosurgery (2013) 73:1001-6; discussion: 6 . doi: 10.1227/NEU.0000000000000148

58. Atalar B, Choi CY, Harsh GR IV, Chang SD, Gibbs IC, Adler JR, et al. Cavity volume dynamics after resection of brain metastases and timing of postresection cavity stereotactic radiosurgery. Neurosurgery (2013) 72:180-5; discussion: 5. doi: 10.1227/NEU.0b013e31827b99f3

59. Asher AL, Burri SH, Wiggins WF, Kelly RP, Boltes MO, Mehrlich M, et al. A new treatment paradigm: neoadjuvant radiosurgery before surgical resection of brain metastases with analysis of local tumor recurrence. Int J Radiat Oncol Biol Phys. (2014) 88:899-906. doi: 10.1016/j.ijrobp.2013.12.013

60. Vogel J, Ojerholm E, Hollander A, Briola C, Mooij R, Bieda M, et al. Intracranial control after Cyberknife radiosurgery to the resection bed for large brain metastases. Radiat Oncol. (2015) 10:221. doi: 10.1186/s13014-015-0523-4

61. Wang CC, Floyd SR, Chang CH, Warnke PC, Chio CC, Kasper EM, et al. Cyberknife hypofractionated stereotactic radiosurgery (HSRS) of resection cavity after excision of large cerebral metastasis: efficacy and safety of an 800 cGy x 3 daily fractions regimen. J Neurooncol. (2012) 106:601-10. doi: 10.1007/s11060-011-0697-z

62. Al-Omair A, Soliman H, Xu W, Karotki A, Mainprize T, Phan N, et al. Hypofractionated stereotactic radiotherapy in five daily fractions for postoperative surgical cavities in brain metastases patients with and without prior whole brain radiation. Technol Cancer Res Treat. (2013) 12:493-9. doi: $10.7785 /$ tcrt.2012.500336
63. Kim PK, Ellis TL, Stieber VW, McMullen KP, Shaw EG, McCoy TP, et al Gamma Knife surgery targeting the resection cavity of brain metastasis that has progressed after whole-brain radiotherapy. J Neurosurg. (2006) 105(Suppl.):75-8. doi: 10.3171/sup.2006.105.7.75

64. Eaton BR, LaRiviere MJ, Kim S, Prabhu RS, Patel K, Kandula S, et al. Hypofractionated radiosurgery has a better safety profile than single fraction radiosurgery for large resected brain metastases. J Neurooncol. (2015) 123:103-11. doi: 10.1007/s11060-015-1767-4

65. Suki D, Hatiboglu MA, Patel AJ, Weinberg JS, Groves MD, Mahajan A, et al. Comparative risk of leptomeningeal dissemination of cancer after surgery or stereotactic radiosurgery for a single supratentorial solid tumor metastasis. Neurosurgery (2009) 64:664-74; discussion: 74-6. doi: 10.1227/01.NEU.0000341535.53720.3E

66. Johnson MD, Avkshtol V, Baschnagel AM, Meyer K, Ye H, Grills IS, et al. Surgical resection of brain metastases and the risk of leptomeningeal recurrence in patients treated with stereotactic radiosurgery. Int $J$ Radiat Oncol Biol Phys. (2016) 94:537-43. doi: 10.1016/j.ijrobp.2015. 11.022

67. Atalar B, Modlin LA, Choi CY, Adler JR, Gibbs IC, Chang SD, et al. Risk of leptomeningeal disease in patients treated with stereotactic radiosurgery targeting the postoperative resection cavity for brain metastases. Int J Radiat Oncol Biol Phys. (2013) 87:713-8. doi: 10.1016/j.ijrobp.2013. 07.034

68. Soliman H, Ruschin M, Angelov L, et al. Consensus contouring guidelines for postoperative completely resected cavity stereotactic radiosurgery for brain metastases. Int J Radiat Oncol Biol Phys. (2018) 100:436-42. doi: 10.1016/j.ijrobp.2017.09.047

Conflict of Interest Statement: The author declares that the research was conducted in the absence of any commercial or financial relationships that could be construed as a potential conflict of interest.

Copyright (C) 2018 Masucci. This is an open-access article distributed under the terms of the Creative Commons Attribution License (CC BY). The use, distribution or reproduction in other forums is permitted, provided the original author(s) and the copyright owner(s) are credited and that the original publication in this journal is cited, in accordance with accepted academic practice. No use, distribution or reproduction is permitted which does not comply with these terms. 